College Library Grants Zero-Funded. In the final version of the FY 1984 funding bill (P.L. 98-139), House conferees went along with a Senate-passed action and eliminated all funding for the College Library Resources grants under the Higher Education Act Title II-A. The program authorized $\$ 10,000$ for each qualifying institution, but funding had dwindled to $\$ 1,920,000$ in FY 1983 with grant awards of $\$ 870$ each. As funding levels dropped the program lost its once vocal academic library constituency, thus creating a vicious circle effect.

For the last 3 years, the Senate Appropriations Committee had criticized II-A for its lack of any needs-based criteria for awarding grants. The next move is up to the authorized subcommittees of Congress as they begin the Higher Education Act reauthorization process, and to the academic library community as well. The ACRL Legislation Committee will be considering recommendations on HEA II-A reauthorization at the ALA Midwinter Meeting in January in Washington, D.C. Committee chair Elaine Sloan, dean of university libraries at Indiana University (Bloomington, IN 47401) would welcome suggestions .

FY 1984 will be the first time since HEA funding began in 1966 that II-A is without funds. Funding is continued at 1983 levels for HEA II-B Training and Research $(\$ 880,000)$ and II-C Research Libraries ( $\$ 6$ million). The Library Services and Construction Act Titles I and III were raised to their authorized ceilings of $\$ 65$ million and $\$ 15$ million respectively, the highest levels ever appropriated for public library services and interlibrary cooperation.

Telecommunications Costs Rising. Pending telecommunications developments --the divestiture of AT\&T, the Federal Communications Commission's decision to levy access charges for local connection to long distance circuits, and proposed tariffs filed by AT\&T for its telecommunications services--will have a major impact on library and information services. These developments were discussed with several resource persons and telecommunications experts at a recent Library of Congress Network Advisory Committee meeting on telecommunications.

A drastically changed rate structure for the private leased lines used by libraries to transmit bibliographic data could bring increases of $60 \%$ and more by next April. Circuit charges for OCLC participants would go up from around $\$ 485,000$ per month to about $\$ 775,000$, according to a recent preliminary analysis. Similar increases would apply to RLIN and other library systems relying on dedicated leased lines. There may also be increases of $5 \%-15 \%$ in dial-access telecommunications charges for users of value-added networks.

The House on November 10 passed legislation (H.R. 4102) which repealed the FCC access charges for residential customers and single-line businesses, but gave no relief to leased-line users. However, Rep. Bill Ford (D-Mich.) raised the issue of the impact of the private-line tariff on library data transmission costs. He recommended that both Congress and the FCC look at the issue further (see the November 10 Congressional Record, pp. H9649-50), Daily Edition). Both ALA and the Association of Research Libraries will have filed comments with the FCC by the time you read this. 


\section{Thinking Computing?...}

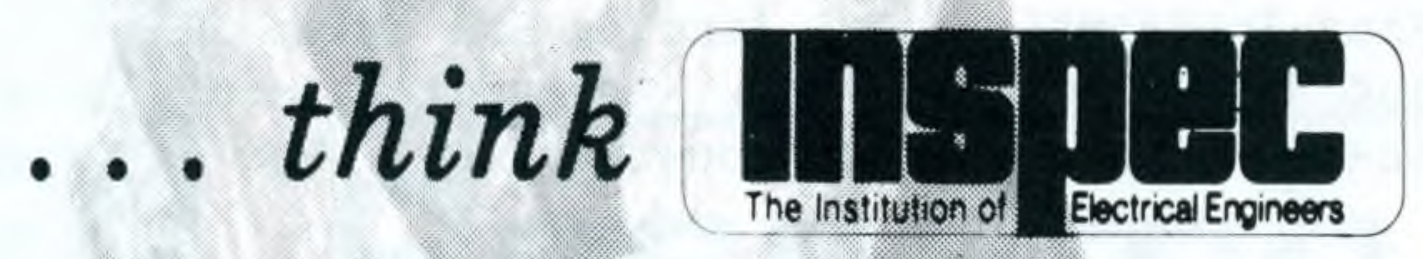

\section{The world's most comprehensive information service in computing}

INSPEC covers all aspects of the subject - software, hardware from micros to mainframes, systems and the whole range of computer applications. To do this, INSPEC scans over 500 journals, numerous conference proceedings, reports and books.

Details of the journals have been collected in a new publication Periodicals in Computing which is available free of charge.

To obtain your free copy, just clip the coupon below and return it to:

$\mathrm{UK}$

INSPEC Marketing Department. Institution of Electrical Engineers.

Station House,

Nightingale Road,

Hitchin, Herts. SG5 1RJ

Tel. 046253331

Telex 825962 IEE or US

INSPEC.

IEEE Service Centre,

445 Hoes Lane,

Piscataway, NJ 08854

USA

Tel. $\$ 20119810060$

Telex 833233 IEEE PWAY

Please send my copy of Periodicals in Computing plus details of INSPEC's information services in computing

Name

Company

Address

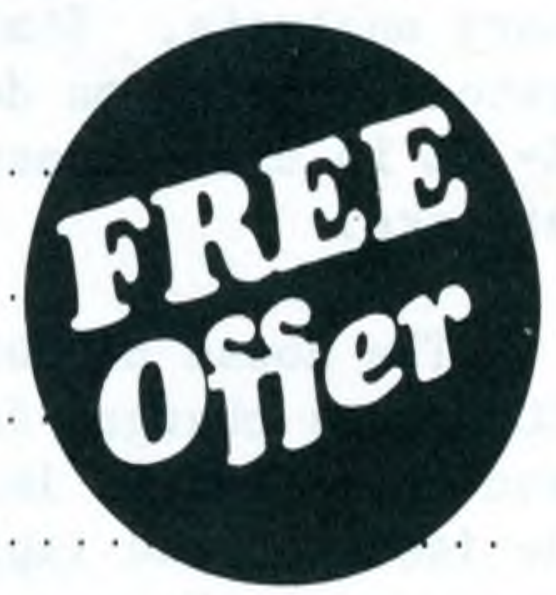

Tel.

Telex

I am currently a user of INSPEC services 